\title{
The Role of Tourism in Development: A Dilemma Between Economic Growth and Mangrove Forest Degradation (A Case Study of Regencies/Cities in North Maluku Province)
}

\author{
Elia Radianto", Titi Susilowati Prabawa, Wilson M. A. Therik, Gatot Sasongko, Marthen Luther Ndoen
}

Development Studies of Interdisciplinary Faculty, Satya Wacana Christian University, Jl. Diponegoro No. 52-60, Salatiga, Indonesia 50711

Received October 22, 2019/Accepted November 29, 2019

\begin{abstract}
The establishment of the Morotai Island Regency as one of the 10 National Tourism Strategic Areas and Special Economic Zones is a central government strategy to accelerate the development of regencies/cities in North Maluku Province, which are still classified as underdeveloped regions in Eastern Indonesia. This study aims to analyze the influence of tourist arrival rate, price, human development index, and tourism promotion policy on economic growth by using regression of panel data offixed-effect model (FEM) based on the feasible generalized least square (FGLS) VI method in eight regencies/cities in North Maluku Province during the period of 2012-2017. This finding shows that tourism development was closely related to economic growth, both in the short and long term. However, the development of tourism facilities and other supporting tourism facilities on the coast by coastal landfill had sacrificed the growth of coastal mangrove forests. Therefore, the local government is encouraged to issue regional regulations on the implementation of sustainable tourism businesses and educate the local community and visitors to play a role in protecting the environment of tourist destinations sustainable.
\end{abstract}

Keywords: economic growth, tourism promotion policy, mangrove forest degradation, sustainable tourism, feasible generalized leastsquare

*Corresponding author,email: eliaradianto@yahoo.com

\section{Introduction}

As one of the important sectors in international trade, tourism has become a significant source of foreign exchange earnings in various countries. World Travel and Tourism Council (WTTC, 2019) believed that it was able to contribute $10.4 \%$ of gross domestic product (GDP) and 319 million jobs, or $10 \%$ of total global employment in 2018. In the economic sector, it was able to provide a multiplier effect, especially for the development of other associated industries. Similarly, this sector has a direct impact reflected through shopping or tourist spending on typical tourism products and entrance fees to tourist destinations. While the indirect impact is in the form of an increase in purchasing power for locally produced semi-finished goods for hotel and restaurant purposes.

Apart from the tourism popularity as reported by the WTTC (2019), in-depth studies are highly needed, specifically on the role of the tourism sector to improve the economic growth in a region or a country. In 2005, Oh carried out a research that applied the two-stage Enggle and Granger and bivariate vector autoregression (VAR) model and used quarterly data (during the first quarter of 1975 to the first quarter of 2001). As a result, $\mathrm{Oh}$ (2005) found that the tourist arrival rate did not influence economic growth. Ohs' hypothesis was stating that the economic growth led by tourism does not support the Korea economics context due to a rapid economic expansion, which caused a tendency in the tourist arrival only in the short term.

However, $\mathrm{Ng}$ and $\mathrm{Du}$ (2011) state that there were probably two methodological weaknesses in the study, which caused the results of an analysis of economic growth led by tourism to be insignificant. First, the priority of the approach was not motivated by the economic theory but on the econometric approach. Second, researches generally only focused on individual countries so that tourism did not have marginal explanatory power. Therefore, by using the quantile regression model according to the least-squares method based on a sample of 109 countries during the period of 1995-2011, it could be proven that the hypothesis of economic growth led by tourism (number of tourist arrivals, gross capital formation, average school age as a proxy for source quality human resources, and percentage of expenditure for R \& D) could be accepted according to theory. Similarly, by applying least square dummy variable (LSDV) method, Nunes and Sequira (2011) found that the 
tourism arrival rate (tourist arrival rate/number of population) and income variable (share of tourist income on gross domestic product) positively influenced the economic growth, both for big or small countries (had less than 5 million population) and poor countries with below-average GDP per capita during the period of 1980-2002.

In contrast, previous research by Anggraeni (2017), which used panel data of the Fixed Effect Model in eight ASEAN countries during the period of 2000-2012, found that the international tourist arrival variable significantly influenced the economic growth, which was following the hypothesis of economic growth led by tourism. Sadiku et al. (2017) took a sample of 6 Western Balkan countries during 1998-2014, and according to panel data regression, it was found that the tourist arrival rate, tourist reception, private investment, and government spending had a positive effect on real per capita income in the long run. A study by Zeren (2018), which used Dynamic Common Correlated Effects Mean Group Estimator in 81 provinces during the period of 2000-2015 in Turkey, found that tourist arrival and length of stay variables were positively related to the economic growth as the higher the tourist arrival rate and length of stay, the more the spending and the more positive the impact on economic growth.

Meanwhile, a previous research by Pin et al. (2016), which used a quantile regression model in 109 countries during 1995-2011, added that besides the number of tourist arrivals, the price level (foreign exchange rate) variable was also significant for the economic growth. In addition, the study concluded that the hypothesis on tourism-led economic growth was acceptable according to theory. Further, a study of Guerrero et al. (2015), which used a multiple regression analysis in Andalucía, Spain in the period of 2005-2012, found that the tourist arrivals, number of starred hotels, average tourism industry income, and Pound sterling exchange rate variables were significant and positive, except the hotel price index which was significant. However, the coefficient was negative, according to the theory. Dwyer et al. (2016) used a dynamic panel data model in four countries in the period of 1990-2008 and added that the price coefficient (that was shown through price competitiveness indicator/PCI using purchasing power parity/PPP) was negative but not significant. It implied that the intended outcome as a result of several things, including the possibility that tourists were very price sensitive as a result of a large number of destinations that tourists could visit and poor travel infrastructure availability.

Similarly, Sadeghi et al. (2011) used a panel vector autoregressive (P-VAR) approach in a sample of 20 developing countries during the period of 1995-2008 and found that the tourist arrival variable was significant for the economic growth. It was concluded that the tourism-led growth hypothesis in developing countries could be confirmed, and it justified the need for government intervention in promoting tourist destinations to increase the number of tourist arrivals to increase the economic growth. Correspondingly, Bashir and Suhel (2018), used Granger causality model and simultaneous equations in South Sumatera Province, Indonesia during the period of 2000-2015 and found that government spending policies to increase tourism promotion were significant to the economic growth and concluded that public policy initiatives for development tourist destinations would have a positive impact on the economic growth.

On the other hand, Butar-Butar et al. (2015), found that the reduced number and function of mangrove forests as a buffer zone for coastal zones in Indonesia was triggered by loosening of licenses issued by regency/city or provincial governments to the private sector for exploitation permits for coastal locations to become tourist destinations that were not environmentally friendly. More specifically, by using SWOT (Strengths, Weaknesses, Opportunities, Threats) analysis, Fithor et al. (2018) found that efforts to bring mass tourism to the opening of Maron Beach in Semarang had caused negative impacts on the mangrove ecosystems in the form of (1) reducing the function of mangroves in protecting the coast from coastal abrasion, (2) reducing the ability of wind abrasion protection, (3) weakening environmental conditions, and (4) reducing fish production.

In contrast to previous researches, Indonesia is currently trying to increase its economic growth through the tourism sector as a driver of development to exploit the potential of tourism in regions through the establishment of 10 National Tourism Development Strategis Areas (kawasan strategis pariwisata nasional/KSPN ${ }^{1}$ ). Morotai Island Regency in North Maluku Province is considered as an under-developed regency in Eastern Indonesia but has a variety of potential natural, cultural, and world-class tourism excellence in the form of World War II Asia Pacific heritage. It has been famous as the "pearl on the lips of pacific" and attracts the Indonesian government to set it in the $10 \mathrm{KSPN}$. In fact, to accelerate the economic development of the surrounding area, the Central Government also set it as a Special Economic Zones (kawasan ekonomi khusus/KEK ${ }^{2}$ ). It is expected that it can accelerate the economic growth through the tourism sector and other associated sectors as well as provide added value in overcoming poverty and job creation, which in turn will increase the prosperity of the community in Morotai Island Regency and other regencies/cities in North Maluku Province.

Figure 1 shows that the existence of KSPN and KEK policies, through the construction of various tourism support facilities as well as tourism promotion funded by the central government through the calendar of events since 2012-2017, has been able to increase the number of tourist arrivals in almost all regencies/cities except West Halmahera Regency which experienced a decrease in tourist arrivals from 17.812 to 6.992 tourists ( $60.75 \%$ declining rate). Likewise, there has also been an increase in changes in the human development index, and price measured using purchasing power parity

\footnotetext{
${ }^{1} 10$ KSPN: 1) Lake Toba (North Sumatera), 2) Kepulauan Seribu and Kota Tua (Jakarta), 3) Borobudur (Central Java), 4) Labuan Bajo (East Nusa Tenggara), 5) Bromo Tengger Semeru (East Java), 6) Wakatobi (Southeast Sulawesi), 7) Tanjung Kelayang (Bangka Belitung), 8) Tanjung Lesung (Banten), 9) Mandalika (West Nusa Tenggara), and 10) Morotai (North Maluku). Morotai Island Regency was determined based on Presidential Regulation Number 50 of 2011

${ }^{2}$ Established based on Presidential Regulation Number 50 of 2014
} 
(PPP), which have experienced positive growth changes since 2012-2017 in all regencies/cities in North Maluku Province. The existence of changes in positive growth in the four variables referred to is quite influential on the occurrence of changes in economic growth in each regency/city except East Halmahera Regency, which has a negative growth of $6.42 \%$. While other regencies/cities experienced positive growth changes $(13.27 \%$ for West Halmahera, $8.51 \%$ for Central Halmahera, $18.44 \%$ for Sula Islands, $14.78 \%$ for North Halmahera, $13.86 \%$ for Morotai Island, $23.90 \%$ for Ternate City, and $19.78 \%$ for Tidore City). Figure 1 presents all the details.

However, the policy of bringing mass tourism to pursue economic growth with a loose policy to carry out construction of large-scale tourism facilities (for example construction of recreational areas, culinary centers and hotels by making landfill on the coast of Morotai Island) in Morotai Island Regency as one of the KSPN and KEK greatly influenced the growth of mangrove forests. Meanwhile, the mangrove forests helped in maintaining marine and coastal ecosystems and could also be used as an attractive tourist destination. Therefore, further study would be highly needed.

According to the data and explanations mentioned earlier, this study would utilize the panel data model test (pooled data) during the period of 2012-2017 to estimate the influence of tourist arrival rate, spending, human development index, and tourism promotional policies to per capita gross regional domestic product in regencies/cities in North Maluku Province. However, it seemed that the efforts to pursue economic growth by bringing mass tourism through the construction of tourism facilities such as beach recreation parks, culinary centers, and hotels on the coast by coastal landfill had sacrificed the growth of mangrove forests on the coast. This could be seen in the example of the case in the Morotai Island Regency, which showed that in 2005, the area of mangrove forests was 15.618 ha. However, in 2017, the area of mangrove forests had decreased to $1.833 \mathrm{Ha}$ or had decreased by $88.26 \%$. Based on the data referred to and in relation to the demands of development done by the government, it is important to understand the dilemma between the effort to teach coastal tourism development and construction of coastal tourism facilities on the coast of the forest mangroves, so it is interesting to do research.

\section{Methods}

Research design This study used an economic growth model developed by Solow (1956) and was based on several previous studies which examined the contribution of tourism to long-term economic growth (Nunes \& Sequeira, 2011; Zhang, 2015; Pin et al., 2016; Erbas et al. 2017). Compared to previous empirical researches, this study examines the influence of four independent variables (tourist arrival rates, spending, human development index, and tourism promotional policies) on gross regional domestic product per capita as the dependent variable. For this reason, an econometric analysis was conducted using panel data (pooled data) or a combination of time series and cross section data, which allows not only an increase in degrees of freedom and number of samples with a better estimation but also overcome the lack of data by considering specific country or regional effects, have large variability and reduce collinearity between explanatory variables, and produce

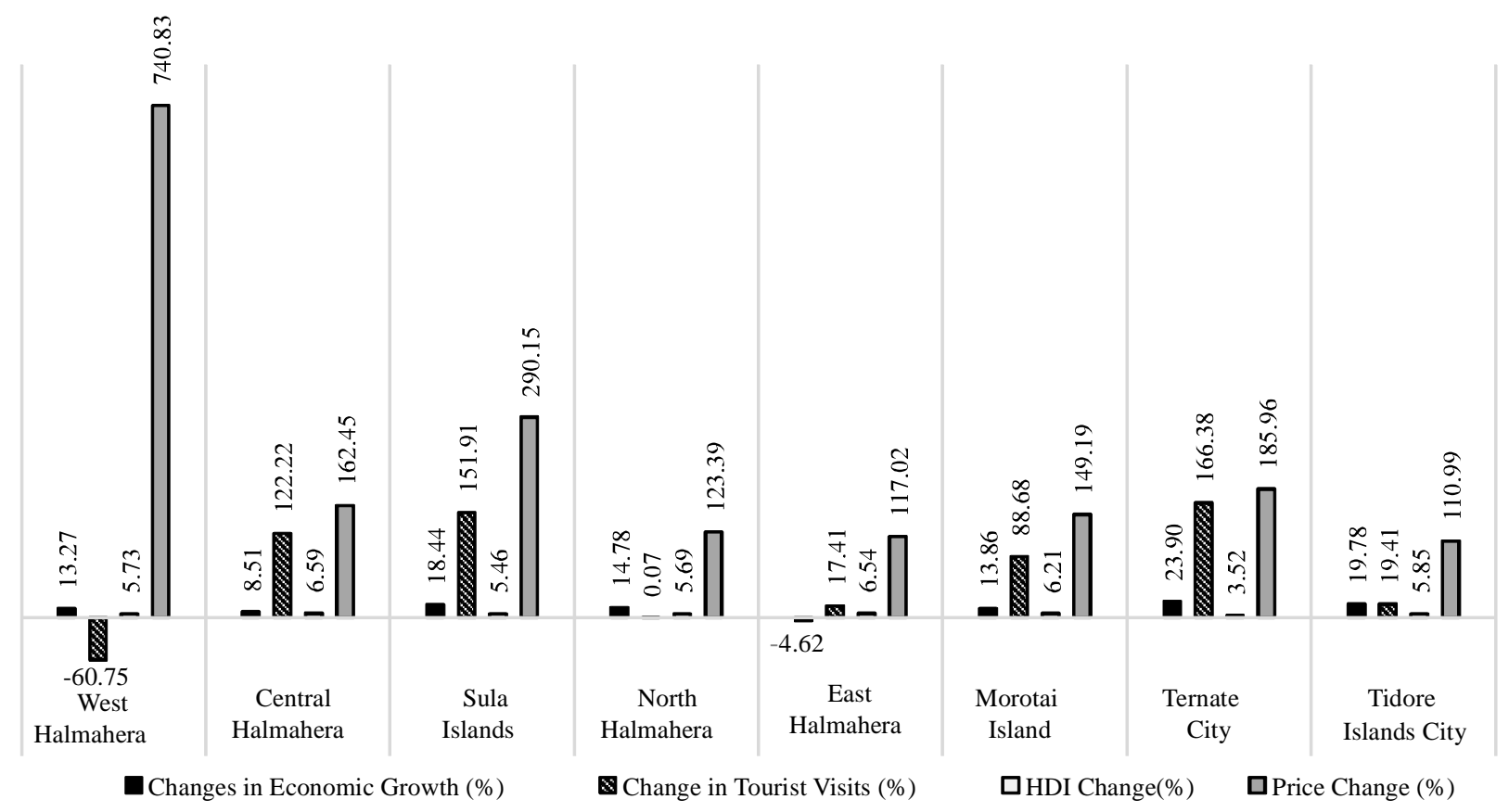

Figure 1 Percentage of change in tourist visits, human development index, price and economic growth (\%) in regencies/cities in North Maluku Province in 2012-2017. 
efficient econometric estimates (Sequeira \& Nunes, 2008; Petit \& Seetaram, 2012; Susanti, 2013; Susilawati et al., 2014; Yunitaningtyas et al., 2019).

However, Radianto (1995), Insukindro and Radianto (1995), Radianto (2001), Petit and Seetaram (2012), and Leitão (2015) stated that in relation to the use of the best model according to econometric criteria, the use of the model must be able to consider the current conditions depending on the conditions of the previous year and should be considered capable in covering a limited amount of data for a long-term analysis as expected by the theory. In other words, the model referred to should be able to calculate the extent of the current visit depending on the number of previous visits by considering the dissemination of information carried out by tourists in previous years.

Furthermore, according to Susilawati et al. (2014), and Yunitaningtyas et al. (2019), the pseudo-variable of the fixed effect model is still based on the feasible generalized least square (FGLS) method and could be used in regression equations that have few cross-tabulation objects. Similarly, Greene (2012) and Ekananda (2016) added that the use of dynamic linear models using the VI instrument variable could be used to analyze the long-term influence of the variables used. Therefore, by considering the opinion referred to, to test the hypothesis of economic growth led by tourism, in the long run, the dynamic panel data analysis would be used as a reference.

Empirical variables and model used This study used the gross regional domestic product (GRDP) per capita variable (as the dependent variable) and tourism participation index (TPI) (as the independent variable, TPI is a ratio between the number of tourist arrivals and the number of population in the destination area). The spending was measured by using purchasing power parity (PPP) as a proxy of the price (P). Others analyses used in this study are human development index (as a proxy for human resources quality/HDI) and dummy tourism promotional policy (DTPP). The DTPP is the governments' policy to promote tourism in the form of an annual tourism festival event carried out and/or participated by regencies/cities through government funds (State Budget and Regional Budget) (as a proxy of tourism promotional policy). While the data used in this study were time-series data from 2012 to 2017 with eight out of ten regencies/cities. The consideration for choosing the sample was because the two regencies (South Halmahera and Taliabu Island) were newly expanded regions. Therefore, the researchers were faced with data availability problems, and adjustments were made to the availability of data in the eight regencies/cities in question. Table 1 presents the definition of variables used.

By observing the data and variables used in Table 1, a basic model would be derived to test the growth hypothesis led by tourism (Prasad et al., 2010; Ng \& Du, 2011; Nunes \& Sequeira, 2011; Pin et al., 2016; Sadiku et al., 2017; Bogdan et al., 2018; Zeren, 2018) to the Equation [1].

$\mathrm{Y}=f(\mathrm{TPI}, \mathrm{P}, \mathrm{HDI}, \mathrm{DTPP})$

Then, from the theoretical model of Equation [1], it can be derived into the general form of economics as is expressed in Equation [2].

$\mathrm{Y}_{\mathrm{it}}=\beta_{0}+\beta_{1} \mathrm{TPI}_{\mathrm{it}}+\beta_{2} \mathrm{P}_{\mathrm{it}}+\beta_{3} \mathrm{HDI}_{\mathrm{it}}+\beta_{4} \mathrm{DTPP}_{\mathrm{it}}+\mu_{\mathrm{it}}$

note: $\mathrm{Y}=$ economic growth; TPI = level of tourist arrivals; $\mathrm{P}$ = price of commodities consumed by tourists; HDI = human development index; and DTPP = dummy of tourism promotion policy. Then, $\mathrm{i}=1,2, \ldots \mathrm{N} ; \mathrm{t}=1,2, \ldots, \mathrm{T}$, or in other words, the $\mathrm{i}$-index shows the dimensions of the crosssection, and the t-index represents the time which indicates the time-series dimensions. While $\beta_{0}$ is a constant, $\beta_{1}, \beta_{2}, \beta_{3}$

Table 1 Definition of variables used

\begin{tabular}{lllll}
\hline \multicolumn{1}{c}{ Variable } & Symbol & \multicolumn{1}{c}{ Description } & \multicolumn{1}{c}{ Unit } & Source \\
\hline Real GRDP per capita & Y & $\begin{array}{l}\text { Constant Price of GRDP per } \\
\text { capita } 2010=100\end{array}$ & Thousand Rupiah & $\begin{array}{l}\text { Central Bureau of } \\
\text { Statistics (BPS) }\end{array}$ \\
$\begin{array}{l}\text { Tourism } \\
\text { Participation Index }\end{array}$ & TPI & Number of Tourist/ Population & Number of Tourist/ \\
Price of commodity \\
$\begin{array}{l}\text { consumed by tourists } \\
\text { Puality of Human }\end{array}$
\end{tabular}

note: Used of Tourism Participation Index (TPI) - a measure of Human Tourism Indicator (HTI) which is an indicator that shows the achievement of regional economic development due to tourist arrivals; P is Price Competitiveness Indicator (PCI) by using Purchasing Power Parity (PPP), showing the price of commodities consumed by tourists while they are in the destinations; Human Development Index (HDI) shows the quality of human resources developed by the World Travel and Tourism Council (WTTC). 
and $\beta_{4}$ are the measured parameters; and $\mu=$ error term.

The next step before lowering the empirical model estimated. There were two-phase procedures for panel data testing, which aimed to choose the best panel data model in estimating the empirical model to be used. The intended procedures were Chow and Hausman Test which aimed to obtain the best model among the three panel data models (common effect model or pooled ordinary least squares/PLS, random effect model/REM, and fixed effect model/FEM) (Sequeira \& Nunes, 2011; Petit \& Seetaram, 2012; Susanti, 2013; Susilawati et al., 2014; Ekananda, 2016; Yuliana \& Sitorus, 2018; Yunitaningtyas et al., 2019). The tests can be explained as follows:

Chow test This first step was to determine the use of FEM or PLS that was most appropriate to be used in estimating panel data. The hypotheses in this test are (Baltagi; 2005; 2008; Gujarati, 2003):

$\mathrm{H}_{0}=$ PLS

$\mathrm{H}_{1}=\mathrm{FEM}$

If the $\mathrm{F}_{\text {-count }}>\mathrm{F}_{\text {-table }}$, then $\mathrm{H}_{0}$ is rejected and means that the most appropriate model to use is the FEM and vice versa where if $\mathrm{F}_{\text {-count }}<\mathrm{F}_{\text {-table }}$, then $\mathrm{H}_{0}$ is accepted and means that the most appropriate model to use is the PLS. The F statistical calculations using the Chow test is as follows as Equation [3]

$$
F=\frac{\left(S E E_{1}-S E E_{2}\right) /(N-1)}{S E E_{2} /(n t-n-k)}
$$

note: SEE1= sum square error of the common effect model; SEE2 $=$ sum square error of the fixed effect model; $\mathrm{n}=$ number of regencies/cities (cross-section); $n t=$ number of cross-sections $\times$ number of time series; $\mathrm{k}=$ number of independent variables;

Whereas the F table is obtained from:

$$
F_{- \text {table }}=\{\alpha: d f(n-1, n t-n-k)\}
$$

note: $\alpha=$ significance level used $(\alpha) ; \mathrm{n}=$ number of regencies/cities (cross-section); nt $=$ number of crosssections $\times$ number of time series; $\mathrm{k}=$ number of independent variables.

Hausman test The second step used to determine which model was more suitable between the FEM or the REM. This should be done for the selection of models with a constant and random effect using the Hausman test. In this test, the effect of the error terms could always be random. However, in the dummy variable model, the nature of randomity was limited in the sample data used. By using the error components model, the obstacles were assumed to be random for the entire population, whereas the dummy variable model did not assume that. Therefore, the dummy variable model could be used more freely. However, if the randomity assumption occurred, then the assumption increased the efficiency of the estimation. For this reason, the Hausman test was carried out as explained below (Baltagi 2003; 2005; 2008; Ekananda, 2016) as shown as Equation [5]

$\operatorname{Var}[b-\beta]=\operatorname{Var}[b]+\operatorname{Var}[\beta]-\operatorname{Cov}[b, \beta]-\operatorname{Cov}[b, \beta]^{\prime}$

Hausman test shows that the covariance of the most efficient estimator $(\beta)$ with the inefficient difference estimator $(b-\beta)$ is zero. It is stated by Equation [5a] and Equation [5b]

$$
\operatorname{Cov}[(b-\beta), \beta]=0,
$$

where $\operatorname{Cov}[(b-\beta), \beta]=\operatorname{Cov}[b, \beta]-\operatorname{Var}[\beta]$ therefore

$$
\operatorname{Cov}[b, \beta]-\operatorname{Var}[\beta]=0 \text { or } \operatorname{Cov}[b, \beta]=\operatorname{Var}[\beta]
$$

Furthermore, this equation substituted in the equation above will be:

$$
\begin{aligned}
& \operatorname{Var}[b-\beta]=\operatorname{Var}[b]+\operatorname{Var}[\beta]-\operatorname{Var}[\beta]-\operatorname{Var}[\beta] \\
& \operatorname{Var}[b-\beta]=\operatorname{Var}[b]+\operatorname{Var}[\beta]=\Sigma
\end{aligned}
$$

The rejection of the Hausman statistic indicated the rejection of the fixed effect model or dummy variable. Therefore, the greater the Hausman statistical value, the greater the acceptance of the alleged component model. Then, based on the Wald's criteria, the Chi-Square test should be:

$$
\mathrm{W}=\chi(\mathrm{K})=[\mathrm{b}-\beta]^{\prime} \Sigma^{-1}[\mathrm{~b}-\beta]
$$

note: $\mathrm{K}=$ number of parameters; $\mathrm{b}=$ the random effect (without intercept) parameter; $\beta=$ the fixed effect parameter using the least square dummy variable (LSDV); var (b) = parameter covariance matrix (without intercept) random effects; $\operatorname{var}(\beta)=$ covariance matrix (fixed effect parameters)

In other words, the conditions that must be met are as follows:

Chi stat $>$ Chi-table $\rightarrow$ Fixed effect (individual effects correlated with independent variables)

Chistat $<$ Chi-table $\rightarrow$ Random effect (there is no relationship between individual effects with independent variables).

If a panel data model had been found with a constant and random effect throughout the observation period as the two tests mentioned referred to, then Equation [2] could be derived into a dynamic economic growth function that could be estimated as an empirical model according to the following model:

$\mathrm{Y}_{\mathrm{it}}=\beta_{0}+\beta_{1} \mathrm{TPI}_{\mathrm{it}}+\beta_{2} \mathrm{P}_{\mathrm{it}}+\beta_{3} \mathrm{HDI}_{\mathrm{it}}+\beta_{4} \mathrm{DTPP}_{\mathrm{it}}+\beta_{5} \mathrm{Y}_{\mathrm{it}-1}+\mu_{\mathrm{it}}$ [7]

Based on Equation [7], a natural logarithmic transformation was performed for all variables except the tourism promotions' policy dummy variable as follows as Equation [8]:

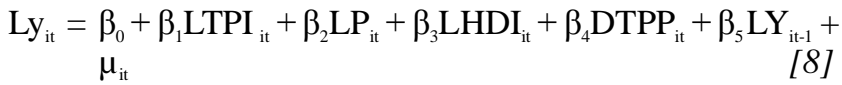

In Table $2, \beta_{1}, \beta_{2} \beta_{3}$, and $\beta_{4}$ were not zero and statistically significant, it indicated that TPI, P, HDI, and DTPP had a

Tabel 2 Hypothesis testing for Equation [8]

\begin{tabular}{lllll}
\hline Ho: $\beta_{1}=0$ & Ho: $\beta_{2}=0$ & Ho: $\beta_{3}=0$ & Ho: $\beta_{4}=0$ & Ho: $\beta_{5}=0$ \\
Ha: $\beta_{1} \neq 0$ & Ha: $\beta_{2} \neq 0$ & Ha: $\beta_{3} \neq 0$ & Ha: $\beta_{4} \neq 0$ & Ha: $\beta_{5} \neq 0$ \\
\hline
\end{tabular}


positive effect on $\mathrm{Y}$. Whereas if $\beta_{5}$ was not zero and statistically significant, there was a long-term effect on $Y_{t-1}$ in estimating the long-term effects of TPI, P, HDI, and DTPP variables on $Y$. Furthermore $\mathrm{i}=1,2, \ldots \mathrm{N} ; \mathrm{t}=1,2, \ldots, \mathrm{T}$, or in other words, the i-index showed dimensions of the crosssection, and the t-index represented the time which indicated the time-series dimensions. While $\beta_{0}$ was an intercept, the $\beta_{1}$, $\beta_{2}, \beta_{3}, \beta_{4}$ and $\beta_{5}$ were the measured parameters. Whereas $\mu$ was an error term, and the underlying assumption was that the independent variable was non-stochastic, and the error term followed the classical assumption $E\left(\mu_{i t}\right) \sim \mathrm{N}\left(0, \sigma^{2}\right)$.

\section{Results and Discussion}

Selecting the FEM or PLS model by Chow test To determine the use of the FEM or PLS, which was most appropriate to use in estimating panel data, a Chow Test was carried out whose calculations can be seen in Table 3. It was found that the $\mathrm{F}_{\text {-count }}$ is greater than $\mathrm{F}_{\text {-table }}(453.01>3.34)$. Therefore, the appropriate model is FEM.

Selecting REM or FEM by Hausman test The Hausman and Likelihood Ratio tests were carried out to determine which model was the most appropriate between the REM or FEM based on the econometric criteria presented earlier.

The results show that the critical value of $\mathrm{Chi} \mathrm{Sq}$ statistics with degree of freedom (df) 4 at $\alpha=5 \%(4 ; 0.05)=$ 9,49 which shows that the Chi-Sq count $\left(\chi_{\text {count }}^{2}=10.819574\right)$ is greater than the $\mathrm{Chi}_{\text {table }}\left(\chi_{\text {table }}^{2}\right.$ d.f. $\left.3 ; \alpha=5 \%=9.49\right)$. Thus, $\mathrm{HO}$ is rejected and indicated that the estimation with fixed effect was better or reflected the data better. The comparison of Hausman test is presented in Table 4.

A long-term analysis by using FEM with FGLS VI To obtain the best and efficient model in accordance with the LSDV method, the FGLS method with instrument VI variables needs to be tested for heteroscedasticity and autocorrelation. According to Hsiao (2003), Baltagi (2005), Baltagi (2008), Greene (2012), and Hassler et al. (2012), heteroscedasticity and autocorrelation often appeared in timeseries data, as panel data sets had proximity to cross-location data on one side and also used time-series data. The existence of heteroscedasticity would result in a consistent estimate of the regression coefficient, but it had an inefficient estimate. Therefore, there would be an error in the estimation standard and would be biased.

For this reason, heteroscedasticity testing using the estimation method of weighted least square (WLS) or often referred to as generalized least square (GLS). Table 5 shows that the value of sum square residual in weighted statistics (SSRWS) is smaller than the value of sum square residual in unweighted statistics (SSRUS) $(0.006981<0.008983)$. Thus, it can be said that the FGLS VI model avoided heteroscedasticity.

Autocorrelation detection should be done to avoid the frequent variation of data in time series data on panel data so that it caused a consistent regression estimation, but the estimation coefficient was not efficient, and the error standard was biased (Baltagi 2005; 2008; Greene, 2012). However, the

Table 3 Results of selecting common effect model or fem selection by Chow test

\begin{tabular}{ccccl}
\hline Effect test & Statistic & df & Comparing & \multicolumn{1}{c}{ Hypothesis } \\
\hline Chow test & 130.69 & F-table d.f. 7.44; & $453.01>3.34$ & Rejection $\mathrm{H}_{0}$ or \\
& & & & Fixed Effect Model \\
\hline
\end{tabular}

Source: Results of data processing with E-views 10

Table 4 Results of selecting REM or FEM

\begin{tabular}{ccccc}
\hline Effect test & Statistic & df & p-Value & \multicolumn{1}{c}{ Hypothesis } \\
\hline Hausman test & 22.323863 & $\chi_{\text {table d.f. } 4 ;}^{2}$ & 0.0002 & $\begin{array}{l}\text { Rejection } \mathrm{H}_{0} \text { or } \chi_{\text {count }}^{2} \\
\end{array}$ \\
& & $\alpha=5 \%=9.49$ & & $\chi_{\text {count }}^{2}>\chi_{\text {table }}^{2}$ \\
\hline
\end{tabular}

Source: Results of data processing with E-views 10

Table 5 Results of heteroscedasticity detection with FGLS VI and white heteroscedasticity

\begin{tabular}{llll}
\hline \multicolumn{3}{l}{ Effects specification } \\
\hline Cross-section fixed (dummy variables) & & & \\
\hline & \multicolumn{2}{c}{ Weighted statistics } \\
\hline R-squared & 0.998066 & Mean dependent var & 11.64358 \\
Adjusted R-squared & 0.997206 & S.D. dependent var & 3.862929 \\
S.E. of regression & 0.016080 & Sum squared resid & 0.006981 \\
F-statistic & 1161.128 & Durbin-Watson stat & 2.355674 \\
Prob (F-statistic) & 0.000000 & & 9.757135 \\
\hline & \multicolumn{2}{c}{ Unweighted statistics } \\
\hline R-squared & 0.997056 & Mean dependent var & 2.370237 \\
Sum squared resid & 0.008983 & Durbin-Watson stat
\end{tabular}


results show that the Durbin Watson (DW) test with $n=40$ and 5 explanatory variables obtain $\mathrm{DW}_{\text {table }}$ of $\mathrm{dl}=1.048$ and $\mathrm{du}=1.684$ at $\alpha=0.05$. This indicated that there were autocorrelations (DW count value of 2. 370237 value of 4 - $\mathrm{dl}$ (4 $-1.048=2.952)$ and $4-\mathrm{du}(4-1.684=2.316)$ or $2.279>$ $\left.\mathrm{DW}_{\text {count }}<2.622\right)$, Therefore, it can be said that there was no autocorrelation which showed that the estimation with FGLS VI had been met. Table 6 presents the results of the analysis.

Table 6 shows that the $\mathrm{R}^{2}$ value is 0.997359 . It indicated that variations in changes in the economic growth could be explained by tourist arrival rate, spending, human development index, and tourism promotion policy variables as much as $99.74 \%$, while the rest $0.26 \%$ was influenced by other variables, which were not included in the model.

In the short term, according to Table 6, there were three variables with highly significant hypotheses of a $99 \%$ confidence level. They were hypotheses of TPI, HDI, and DTPP, while the price variable (P) was not significant. Thus, based on the FGLS VI method, the results reveal that the TPI, HDI, and DTPP variables had a positive effect on economic growth. In other words, if there were an increase in the TPI, HDI, and DTPP, it would stimulate the economic growth for Morotai Island Regency and other regencies/cities in North Maluku Province. Although the price $(\mathrm{P})$ variable was not significant, the results were negative and following the theory. It indicated that an increase in prices would cause a decrease in the number of tourist arrivals, which in turn would reduce economic growth.

In the long-term hypothesis, it can be seen in the adjustment variable or the economic growth lag variable $\left(\mathrm{Y}_{\mathrm{t}-1}\right)$, which is significant at the $99 \%$ confidence level. Thus, it could be continued with the calculation of the long-term coefficients of each significant independent variable: TPI (0.0073), HDI (3.447), and DTPP (0.1142). In other words, if there were an increase in the tourist arrival rate, HDI, and tourism promotion policies, it would stimulate positive economic growth in the long run for Morotai Island Regency and other regencies/cities in North Maluku Province.

Pin et al. (2016), stated that tourism did not grow separately, but depended on efficient infrastructure in supporting the movement of goods and people, quality of human resources, level of technology, broader and more diverse development policy strategies, and a tendency to support tourist arrivals to increase the economic growth.

Therefore, an in-depth and comprehensive study of the stipulation of Morotai Island Regency as KSPN and KEK by the Indonesian government was needed to make it an engine of economic growth for the surrounding regencies / cities in North Maluku Province, especially the one related to tourist arrival rate, prices consumed by tourists, quality of human resources, and tourism promotion policies variables, and the sustainability of the environmental ecosystem.

In line with the findings of $\mathrm{Ng}$ and $\mathrm{Du}$ (2011), Sadeghi et al. (2011), Nunes and Sequeira (2011), Pin et al. (2016), Anggraeni (2017), and Zeren (2018), these findings imply that there was a relationship between the tourist arrival rate and economic growth, both in the short and long term. There was a significant influence on the tourist arrival rate variable supported by 143 marine tourism objects $(53.76 \%)$ and 123 natural, cultural, and historical tourism objects $(46.24 \%)$ of the total attractions of 266 in eight regencies/cities observed in North Maluku Province. Table 7 presents the number of tourism objects by type in regencies/cities in North Maluku Province.

The HDI variable, as a proxy for the quality of human resources, was significant for the economic growth during the observation period of 1995 to 2011. This is in line with the finding of $\mathrm{Ng}$ and $\mathrm{Du}(2011)$ that the average school age, as a proxy for human resource quality, was significant according to theory and added that it was necessary for the government

Table 6 Results of test with FGLS VI method in accordance with LSDV

\begin{tabular}{|c|c|c|c|c|c|}
\hline Variable & $\begin{array}{l}\text { Short term } \\
\text { coefficient }\end{array}$ & Std. error & t-statistic & Prob. & $\begin{array}{l}\text { Long term } \\
\text { coefficient }\end{array}$ \\
\hline $\mathrm{C}$ & -3.330713 & 0.872687 & $-3.816615^{* *}$ & 0.0007 & - \\
\hline LTPI & 0.005269 & 0.001494 & $3.525671^{* *}$ & 0.0015 & 0.0073 \\
\hline LP & -0.002791 & 0.004966 & -0.561985 & 0.5788 & -0.0039 \\
\hline LHDI & 2.473839 & 0.320780 & $7.711940 * *$ & 0.0000 & 3.4470 \\
\hline DTPP & 0.101770 & 0.017232 & $5.905974 * *$ & 0.0000 & 0.1142 \\
\hline LY (-1) & 0.282259 & 0.092020 & $3.067350 * *$ & 0.0049 & - \\
\hline
\end{tabular}

Effects specification

Cross-section fixed (dummy variables)

$\begin{array}{lllr}\text { R-squared } & 0.997359 & \text { Mean dependent var } & 9.757135 \\ \text { Adjusted R-squared } & 0.996186 & \text { S.D. dependent var } & 0.279693 \\ \text { S.E. of regression } & 0.017274 & \text { Akaike info criterion } & -5.022258 \\ \text { Sum squared resid } & 0.008057 & \text { Schwarz criterion } & -4.473372 \\ \text { Log likelihood } & 113.4452 & \text { Hannan-Quinn criterion } & -4.823798 \\ \text { F-statistic } & 849.7781 & \text { Durbin-Watson stat } & 2.260825 \\ \text { Prob (F-statistic) } & 0.000000 & & \end{array}$

$* *$, indicating significance at $99 \%$

Long-Term Coefficient $=$ Short-term Coefficient $/ 1$ - Coefficient LY(-1) 
to provide training to prepare the skilled and creative workforce in supporting the tourism sector. However, this study did not only use the average school-age as a proxy for the quality of human resources, but all components of HDI (life expectancy age/LEA, school length expectancy/SLE, average length of school/ALS, and expenditures per capita/EPC) to measure the quality of human resources. Table 8. shows that there is an increase in HDI of regencies/cities in North Maluku Province from 63.93 in 2012 to 67.20 in 2017 or an average increase of $1.00 \%$.
Although the HDI growth of Morotai Island Regency, as a KSPN and KEK region, is above the average regencies/cities in North Maluku Province, its HDI position in 2017 is the lowest and in a 'moderate' HDI group $(60 \leq 60.71<70)$. It was a result of a low SLE, which reaches 12.17 years, ALS of 6.89 years, and EPC adjusted to IDR 6.17 million annually (Table 9). This implied that efforts were needed to improve the dimensions of education and decent living standards, which in turn would support the development of tourism and the growth of a sustainable economy.

Table 7 Number of tourism objects by type in regencies/cities in North Maluku Province in 2017

\begin{tabular}{|c|c|c|c|c|c|}
\hline \multirow{2}{*}{ Regencies/cities } & & \multicolumn{3}{|c|}{ Type of tourism objects } & \multirow{2}{*}{ Total } \\
\hline & Marine & Natural & Cultural & Historical & \\
\hline West Halmahera & 25 & 6 & 22 & 6 & 59 \\
\hline Central Halmahera & 14 & 6 & - & - & 20 \\
\hline Sula Islands & 22 & 2 & - & - & 24 \\
\hline North Halmahera & 7 & 1 & 3 & 3 & 14 \\
\hline East Halmahera & 4 & 2 & 3 & 1 & 10 \\
\hline Morotai Island & 22 & 7 & - & 2 & 31 \\
\hline Ternate City & 20 & 21 & 11 & 6 & 58 \\
\hline Tidore Islands City & 29 & 3 & 2 & 16 & 50 \\
\hline North Maluku Province & 143 & 48 & 41 & 34 & 266 \\
\hline
\end{tabular}

Source: BPS of North Maluku Province, 2018.

Table 8 Development of human development index in regencies/cities in North Maluku Province in 2012-2017

\begin{tabular}{l|c:cc}
\hline \multicolumn{1}{c}{ Regencies/cities } & & \multicolumn{2}{c}{ Human development index } \\
\cline { 2 - 4 } & 2012 & 2017 & Changes percentage $(\%)$ \\
\hline West Halmahera & 60.71 & 64.19 & 5.73 \\
Central Halmahera & 59.94 & 63.89 & 6.59 \\
Sula Islands & 58.83 & 62.04 & 5.46 \\
North Halmahera & 62.94 & 66.52 & 5.69 \\
East Halmahera & 61.73 & 65.77 & 6.54 \\
Morotai Island & 57.16 & 60.71 & 6.21 \\
Ternate City & 75.81 & 78.48 & 3.52 \\
Tidore Islands City & 65.42 & 69.25 & 5.85 \\
\hline North Maluku Province & 63.93 & 67.20 & 5.11 \\
\hline
\end{tabular}

Source: BPS of North Maluku Province, 2018.

Table 9 Development of human development index indicators in regencies/cities in North Maluku Province in 2012-2017

\begin{tabular}{|c|c|c|c|c|}
\hline \multirow{2}{*}{ Regencies/cities } & LEA & SLE & ALS & EPC \\
\hline & 2017 & 2017 & 2017 & 2017 \\
\hline West Halmahera & 65.55 & 13.06 & 7.87 & 7.266 \\
\hline Central Halmahera & 62.80 & 12.92 & 8.37 & 7.688 \\
\hline Sula Islands & 62.60 & 12.38 & 8.33 & 6.859 \\
\hline North Halmahera & 68.94 & 13. 22 & 8.36 & 7.302 \\
\hline East Halmahera & 67.85 & 12.72 & 7.89 & 7.841 \\
\hline Morotai Island & 66.28 & 12. 17 & 6.89 & 6.167 \\
\hline Ternate City & 70.27 & 15. 30 & 11.25 & 12.989 \\
\hline Tidore Islands City & 68.64 & 13.90 & 9.39 & 8.044 \\
\hline North Maluku Province & 67.54 & 13.56 & 8.61 & 7.792 \\
\hline
\end{tabular}

Source: BPS of North Maluku Province, 2018.

Note: LEA = life expectancy age, $\mathrm{SLE}=$ school length expectancy, ALS = average length of school, and EPC $=$ expenditures per capita 
Furthermore, the dummy of the tourism promotion policy (DTPP) variable is also significant to the tourism promotion policies that were funded by government funds (State Budget and Regional Budget). It was indicated by an increase in types of tourism events annually for regencies/cities in North Maluku Province based on the calendar of events, which had a positive effect on growth. Table 10 shows that there are four regencies/cities that promote tourism using state budget funds: West Halmahera Regency from 4 types of event in 2012 to 9 types of event in 2017 (Sigohi ngolo ceremony, adventurous tourism, Orom sasadu, underwater photography competition, diving, exploring Jailolo Bay, culinary festival, Sasadu on the sea, Moloku Kie Raha cultural art exhibition, and tourism exhibition); Morotai Island Regency from 5 types of event in 2012 to 9 types of event in 2017 (fishing competition, underwater photography competition, Laor bailer competition, swimming competition, artificial boat competition, Katinting competition, traditional swimming competition, cultural festival, and tourism exhibition), Ternate City from 5 types of event in 2012 to 8 types of event in 2017 (historical tourism, cultural tourism, marine and natural tourism and local wisdom, Kora-Kora festival, Kololi Kie, underwater photography competition, traditional fishing competition, and tourism exhibition), Tidore Islands City from 8 types of event in 2012 to 11 types of event in 2017 (art tourism, marine and natural tourism, historical tourism, cultural tourism, Parade Juanga, Paji trips, customary festivals, Kirab Agung of Tidore Sultanate, tourism exhibition, fishing festival, and Maitara festival). The other four regencies (Central Halmahera, Sula Islands, North Halmahera, and East Halmahera) used the regional budget and only sent delegates to promote their tourism potential at the Sail Morotai held in Morotai Island Regency as one of the 10 KSPNs.

The findings show that the tourism promotional policy applied in each regency/city by the government aimed to bring in as many tourists as possible to increase economic growth. This is in line with a statement by Bashir and Suhel
(2018), that public policy initiatives were needed for the development of tourist destinations to increase domestic and international tourist demand, and would have a positive impact on the economic growth in the future.

Unfortunately, on a large scale, the policy had not yet considered the environmental aspects which affected the marine and coastal ecosystems. For example, in Morotai Island Regency, it was very easy to get a tourism business permit because without going through an Environmental Impact Analysis. A key informed who worked at the Morotai Island tourism agency that:

The construction of a Rehabilitation Place and Culinary Center, as well as Hotel buildings in the Morotai Island Regency in the coastal area by making landfill have obtained permission from the local government. The permission was not the results of an Environmental Impact Assessment. Similarly, there are no regional regulations governing the "Mangrove Ecosystem Management," which can be used to determine the areas that can be used as coastal tourism businesses. Therefore, we cannot stop legally any development in mangrove forests (M., November 2019).

The above statement had empirical evidence which showed that there were constructions of parks, culinary centers, and hotel buildings in the coastal area of Daruba City by making landfill in the coast of the mangrove forest area, causing the mangrove forests to be damaged and eventually died.

Figure 2 shows that before the development on the coast of Morotai Island, most of its beaches are surrounded by mangrove forests. However, after the development, as explained earlier, it has caused a reduction in mangrove forests (Figure 3, Figure 4).

There is a negative effect in the form of pollution from the building construction (Figure 3, Figure 4). It damaging some of the living mangrove plants next to the northern part of the buildings - which were usually used by fishermen for shelter

Table 10 Number of tourism promotion programs in regencies/cities in North Maluku Province in 2012-2017

\begin{tabular}{|c|c|c|c|c|c|c|}
\hline \multirow{2}{*}{ Regencies/cities } & \multicolumn{6}{|c|}{ Number of types of tourism promotion events } \\
\hline & 2012 & 2013 & 2014 & 2015 & 2016 & 2017 \\
\hline West Halmahera* & 4 & 5 & 7 & 8 & 6 & 9 \\
\hline Central Halmahera** & $\begin{array}{l}\text { Sending } \\
\text { Delegates }\end{array}$ & $\begin{array}{l}\text { Sending } \\
\text { Delegates }\end{array}$ & - & - & - & - \\
\hline Sula Islands** & $\begin{array}{l}\text { Sending } \\
\text { Delegates }\end{array}$ & $\begin{array}{l}\text { Sending } \\
\text { Delegates }\end{array}$ & $\begin{array}{l}\text { Sending } \\
\text { Delegates }\end{array}$ & $\begin{array}{l}\text { Sending } \\
\text { Delegates }\end{array}$ & $\begin{array}{l}\text { Sending } \\
\text { Delegates }\end{array}$ & $\begin{array}{l}\text { Sending } \\
\text { Delegates }\end{array}$ \\
\hline North Halmahera** & $\begin{array}{l}\text { Sending } \\
\text { Delegates }\end{array}$ & $\begin{array}{l}\text { Sending } \\
\text { Delegates }\end{array}$ & $\begin{array}{l}\text { Sending } \\
\text { Delegates }\end{array}$ & $\begin{array}{l}\text { Sending } \\
\text { Delegates }\end{array}$ & $\begin{array}{l}\text { Sending } \\
\text { Delegates }\end{array}$ & $\begin{array}{l}\text { Sending } \\
\text { Delegates }\end{array}$ \\
\hline East Halmahera** & $\begin{array}{l}\text { Sending } \\
\text { Delegates }\end{array}$ & $\begin{array}{l}\text { Sending } \\
\text { Delegates }\end{array}$ & - & - & - & - \\
\hline Morotai Island* & 5 & 5 & 6 & 4 & 5 & 9 \\
\hline Ternate City* & 5 & 6 & 8 & 7 & 7 & 8 \\
\hline Tidore Islands City* & 8 & 8 & 8 & 9 & 9 & 11 \\
\hline
\end{tabular}

Source : Directorate General of Budget, 2018; Effectiveness of the Ministry of Tourism's Budget Allocation on Foreign and Local Tourists..

Note : * Sources of Fund of Tourism Promotion Activities were from the State Budget. ** Source of Fund of Tourism Promotion Activities were from the Regional Budget. 


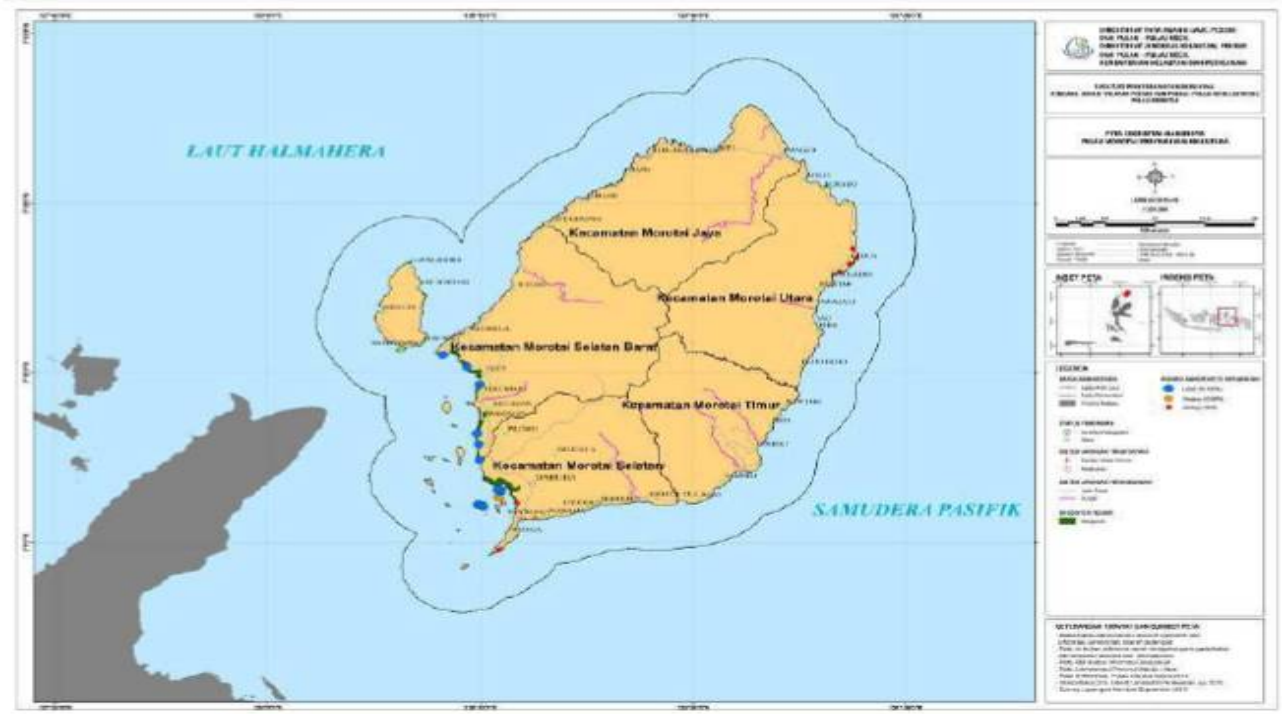

Figure 2 Mangrove ecosystem map on Morotai Island, Morotai Island Regency, North Maluku Province.

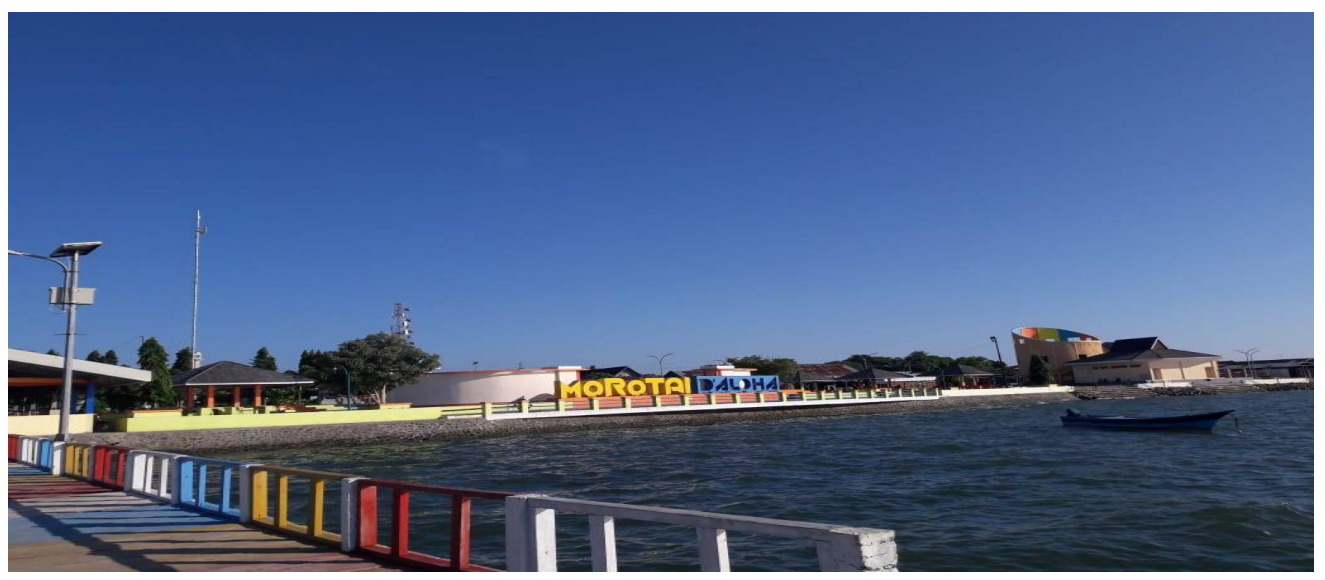

Figure 3 A photo of mangrove beach area that has been covered by landfill and will be developed into the construction of parks, culinary center buildings and hotels in Daruba City, the capital of Morotai Island Regency, seen from the sea towards the coast.

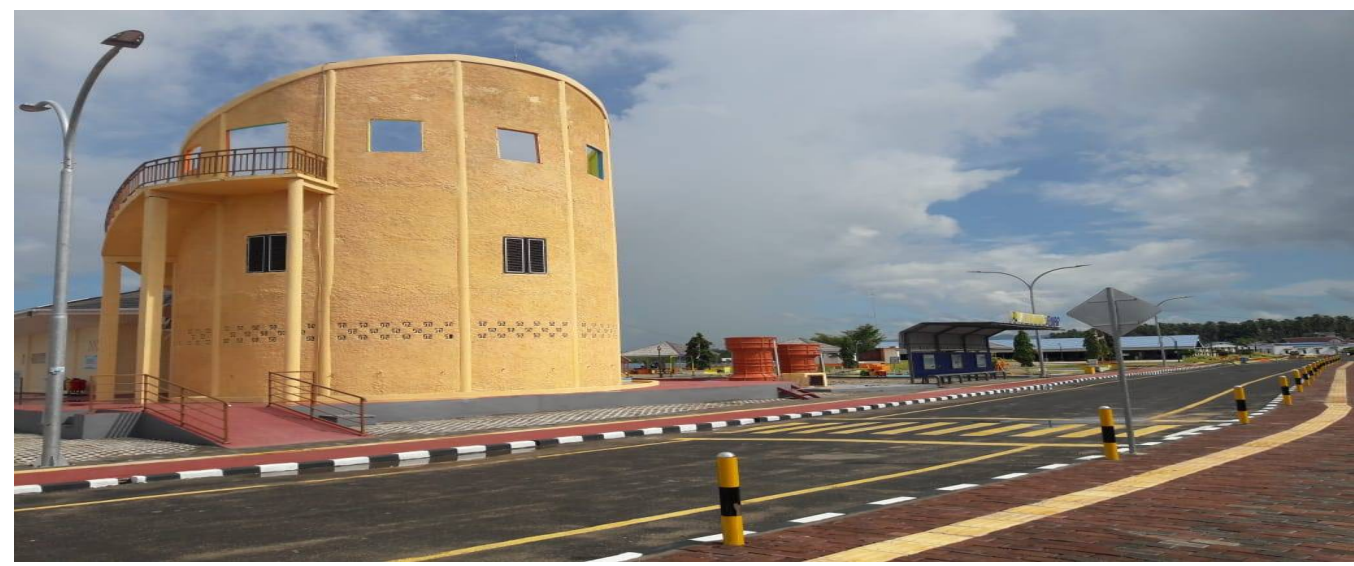

Figure 4 A photo of park, culinary center buildings and hotels on the coast of Daruba City, the capital of Morotai Island Regency, seen from the land to the beach. 
- and some were also dead. Figure 5 picturizes the trail of mangrove forests in the form of dried tree trunks that used to grow in the sea.

The loosen rules, as stated by the key informant and shown by the empirical evidence, showed that it profoundly affected the mangrove forests, and there was a decline in the mangrove forest area and their types. In a research by Ahmad (2014), the data used was from the Central Statistics Agency of Morotai Island since 2005-2017, and it was found that there had been degradation mangrove forest or a decline in the mangrove forest area of $88.26 \%$ or with an average decay per year of $21.18 \%$, and also species of mangrove forests decreased by $26.92 \%$ or with an average annual decrease of 3.43. Table 11 explains the changes affected.

The above findings are similar to the findings of ButarButar et al. (2015) and Fithor et al. (2018) who found that efforts to bring mass tourism (mass tourism) with a loosen licensing policy to the private sector to exploit the coastal area into tourist destinations (which was not environmentally friendly) would atly impact the mangrove ecosystem negatively in the form of (1) reduce the function of mangroves in protecting the coast from coastal abrasion, (2) reduce the ability to protect wind abrasion, (3) weaken environmental conditions, and (4) reduce fish production.

This implied that a policy was needed to minimize the negative effects on the coastal tourism destinations, especially in protecting marine and coastal ecosystems in the form of mangrove forests, seagrass beds and coral reefs. Similarly, by considering the fact that Morotai Island Regency had the potential of fisheries sector in the form of the potential of the Indonesian Archipelagic Sea Lanes III - a tuna migration pathway, it was the right time to take over the development of coastal tourism objects by considering:

(1) in the short term, a study involving relevant technical agencies to issue a Circular Letter which regulated the operation of tourism businesses by considering aspects of environmental and ecosystem sustainability, was needed.

(2) in the long run, a legal organization was needed by involving the legislative role in formulating sustainable tourism development policies by issuing a Regional Regulation on the Implementation of Tourism Businesses.

(3) the role of the government was needed to educate the local community and visitors to protect the environment so that the enchanting beach tourist destinations could have a dual effect in the form of potential attraction of the beauty of tourist destinations and could maintain the potential of

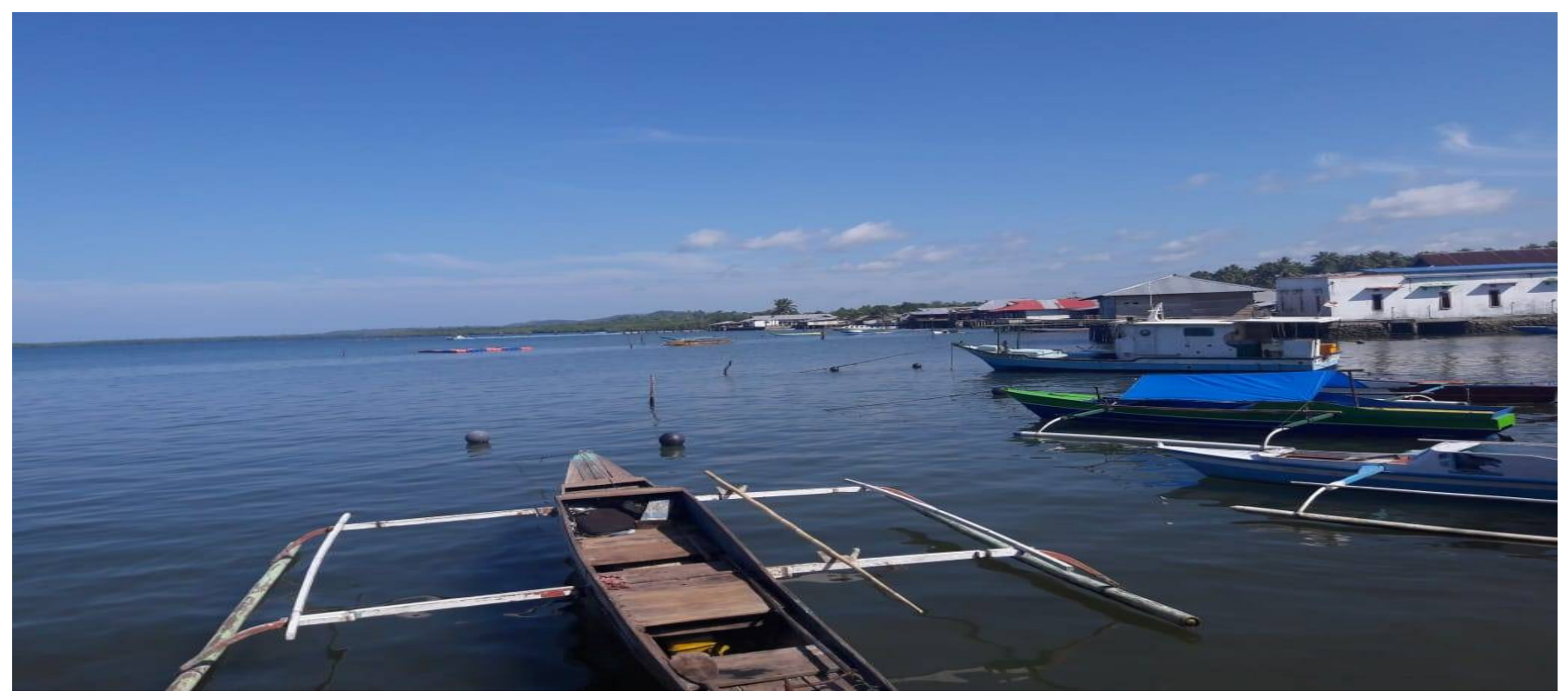

Figure 5 A photo of the remains of dried mangrove trees but can still be used by fishermen to tie their boats to the north side of the park, culinary center building, and hotels on the coast of Daruba City, the capital of Morotai Island Regency.

Table 11 Changes in mangrove forests in Morotai Island Regency

\begin{tabular}{|c|c|c|c|c|c|c|c|c|}
\hline \multirow{2}{*}{ Mangrove forest } & \multicolumn{7}{|c|}{ Year } & \multirow{2}{*}{$\begin{array}{c}\text { Changes } \\
\text { percentage }(\%)\end{array}$} \\
\hline & 2005 & 2012 & 2013 & 2014 & 2015 & 2016 & 2017 & \\
\hline Mangrove forest area (ha) & 15,618 & $1,562.4$ & 1,000 & 1,833 & 1,833 & 1,833 & 1,833 & -88.26 \\
\hline Number of type of mangrove species & 26 & 19 & 19 & 19 & 19 & 19 & 19 & -26.92 \\
\hline
\end{tabular}

Source: Ahmad research data for 2005, and BPS of Morotai Island District data for 2012-2017, several issues 
marine fisheries sustainable.

On the other hand, although the results show that the coefficient of price variable was negative according to the theory, but it was not significant and it was similar to a finding by Dwyer et al. (2016). However, according to Guerrero et al. (2015), although the price variable was negative, but if there was a support for quality services by the private sector, and supported with the availability of qualified infrastructure, it would greatly support an increase in the number of tourists, which in turn would increase the economic growth.

\section{Conclusion}

Based on the results of hypotheses testing of the four independent variables, it shows that there are three significant independent variables (tourism participation index, human development index, and a dummy of tourist promotion policies) except the price variable (P). Similarly, the adjustment variable $\left(\mathrm{Y}_{\mathrm{t}-1}\right)$ was significant. It indicated that the FGLS VI method could be used to predict the effect of each independent variable on the economic growth in the long run. Therefore, it could be concluded that the hypothesis of economic growth led by tourism could apply to Morotai Island Regency as an area of KSPN and KEK, and also other regencies/cities in North Maluku Province. The policy should be reviewed and considered seriously by the government. For example, in the KSPN and KEK areas in the Morotai Island District, the loosen licensing policies had caused the extent of mangrove forests to decrease along the coast of Morotai Island by $88.26 \%$ and also species of mangrove forests decreased by $26.92 \%$. This implied that a policy to minimize the negative effects on the coastal tourism destinations, especially in protecting marine and coastal ecosystems in the form of mangrove forests, seagrass beds, and coral reefs was needed in the form of: (1) in the short term, a study involving relevant technical agencies to issue a Circular Letter which regulated the operation of tourism businesses by considering aspects of environmental and ecosystem sustainability was needed, (2) in the long run, a legal organization was needed by involving the legislative role in formulating sustainable tourism development policies by issuing a Regional Regulation on the Implementation of Tourism Businesses, and (3) the role of the government was needed to educate the local community and visitors to protect the environment, so that the enchanting beach tourist destinations could have a dual effect in the form of potential attraction of the beauty of tourist destinations and could maintain the potential of marine fisheries sustainable. There was also a need of synchronization of programs among regencies/cities in North Maluku Province with KSPN and KEK policies in Morotai Island Regency, so that the two intended government programs can be the engines of economic growth, both in the short and long term for regencies/cities in North Maluku Province and can be a source of foreign exchange earnings for Indonesia.

\section{References}

Ahmad, F. (2014). Jenis-jenis bakau di Daruba dan Wayabula, Pulau Morotai, Maluku Utara. Berita Biologi, 13(3), 255-262. https://doi.org/10.14203/beritabiologi. v13i3669
Anggraeni, G. N. (2017). The relationship between numbers of international tourist arrivals and economic growth in the Asean-8: Panel data approach. Journal of Developing Economies, 2(1), 40-49. https://doi.org/10.20473/jde. v2i13i3.669

[BPS] Central Bureau of Statistics. (2015). Kabupaten Pulau Morotai Dalam Angka Tahun 2015. Kabupaten Pulau Morotai: BPS Kabupaten Pulau Morotai.

[BPS] Central Bureau of Statistics. (2015). Provinsi Maluku Utara Dalam Angka Tahun 2015. Provinsi Maluku Utara: BPS Provinsi Maluku Utara.

[BPS] Central Bureau of Statistics. (2015). Tabel-Tabel Pokok PDRB Provinsi Maluku Utara Menurut Lapangan Usaha Tahun 2015. Provinsi Maluku Utara: BPS Provinsi Maluku Utara.

[BPS] Central Bureau of Statistics. (2018). Indeks Pembangunan Manusia Maluku Utara Tahun 2018. Provinsi Maluku Utara: BPS Provinsi Maluku Utara.

[BPS] Central Bureau of Statistics. (2018). Kabupaten Pulau Morotai Dalam Angka Tahun 2018. Kabupaten Pulau Morotai: BPS Kabupaten Pulau Morotai.

[BPS] Central Bureau of Statistics. (2018). Provinsi Maluku Utara Dalam Angka Tahun 2018. Provinsi Maluku Utara: BPS Provinsi Maluku Utara.

[BPS] Central Bureau of Statistics. (2018). Tabel-tabel pokok PDRB Provinsi Maluku Utara menurut Lapangan Usaha Tahun 2018. Provinsi Maluku Utara: BPS Provinsi Maluku Utara.

Baltagi, B. H. (2003). A companion to theoretical econometrics. New Jersey: Blackwell Publishing Ltd. https://doi.org/10.1111/b.9781405106764.2003.x

Baltagi, B. H. (2005). Econometric analysis of panel data $\left(3^{\text {rd }}\right.$ ed.). Chichester: John Wiley \& Sons Ltd.

Baltagi, B. H. (2008). Econometrics (4 ${ }^{\text {th }}$ ed.). New York: Springer. https://doi.org/10.1007/978-3-540-76516-5

Bashir, A., \& Suhel, S. (2018). The role of tourism toward economic growth in the local economy. Economic Journal of Emerging Markets, 10(1), 32-39. https://doi.org/10.20885/ejem.vol10.iss1.art4

Bogdan, S., Trinajstic, M., \& Baresa, S. (2018). Regional economic growth and tourism: A panel data approach. UTMS Journal of Economics, 9(2), 145-155.

Butar-Butar, F., Sunyowati, D., \& Hastuti, L. (2015). The regulation of sustainable mangroves and coastal zones management in Indonesia. Journal of Civil \& Legal Sciences, 6(1), 1-7. https://doi.org/10.4172/21690170.1000220

Dwyer, L., Seetaram N., \& Forsyth, P. (2016). Measuring price elasticities of demand for outbound tourism using 
competitiveness indices. Annals of Tourism Research, 56(1), 65-79. https//doi: 10.1016/j.annals.2015.10.004

Ekananda. M. (2016). Analisis ekonometrika data panel (Edisi ke-2). Jakarta: Mitra Wacana Media.

Erbas, C. Ü., Muslija, A., \& Satrovic, E. (2017). Panel analysis of tourism-economic growth nexus. International Journal of Economic Studies, 3(4), $535-545$.

Fithor, A., Sutrisno, J., \& Indarjo, A. (2018), Mangrove ecosystem management strategy in Maron Beach Semarang. ILMU KELAUTAN: Indonesian Journal of Marine Sciences, 23(4), 156-162. https://doi.org/ 10.14710/ik.ijms.23.4.156-162

Greene, W. H. (2012). Econometric analysis ( $7^{\text {th }}$ ed.). New Jersey: Prentice Hall.

Guerrero, J. C., Nasir, M. A., \& Wu, J. (2015). Economic growth, exchange rate and constrained competiveness of the tourism sector in Andalucía. International Journal of Management and Economics, 48, 84-100. https://doi.org/10.1515/ijme-2015-0036

Gujarati, D. N. (2003) Basic econometrics (4 ${ }^{\text {th }}$ ed.). New York: McGraw-Hill Companies.

Hassler, U., Kirchgässner, G., \& Wolters, J. (2012) Introduction to modern time series analysis ( $\left.2^{\text {nd }} \mathrm{ed}.\right)$. Berlin: Springer-Verlag Berlin Heidelberg.

Hsiao, C. (2003). Analysis of panel data ( $2^{\text {nd }}$ ed.). Cambridge: Cambridge University Press.

Insukindro, \& Radianto, E. (1995). Analisis faktor-faktor yang mempengaruhi investasi swasta di daerah Maluku. Berkala Penelitian Pasca Sarjana, Universitas Gadjah Mada, Jilid 8, No. 4A, November.

[MoMF] Ministry of Marine and Fisheries. (2017). Review dan Penyempurnaan Masterplan dan Bisnisplan PSKPT di Kabupaten Pulau Morotai. Jakarta: Ministry of Marine and Fisheries.

Leitão, N. C. (2015). Portuguese tourism demand: A dynamic panel data analysis. International Journal of Economics and Financial Issues, 5(3), 673-677.

Ng, P., \& Du, D. (2011). Is tourism a long-run economic growth factor? Working Paper, The W.A. Franke College of Business. Arizona: Northern Arizona University.

Nunes, P. M., \& Sequeira, T. V. (2011). Does tourism influence economic growth? A dynamic panel data approach. Applied Economics, 4, 1-29.

Oh, C. O. (2005). The contribution of tourism development to economic growth in the Korean economy. Tourism Management, 26(1), 39-44. https://doi.org/10.1016/ j.tourman.2003.09.014
Petit, S., \& Seetaram, N. (2012). Panel data analysis in tourism research. Munich Personal RePEc Archive, (75086), 1-27.

Pin, N., Du, D., \& Lew, A. A. (2016). Tourism and economic growth. Journal of Travel Research, 55(4): 454-464.

Prasad B.C., Narayan P.K., Narayan S., Prasad A., 2010. Tourism and economic growth: a panel data analysis for Pacific Island countries. Tourism Economics, 16 (1), 169 $-183$.

Radianto, E. (1995). Spesifikasi dinamis, model investasi jangka panjang: Sebuah studi kasus di Daerah Maluku. Jurnal Ekonomi dan Bisnis Indonesia, BPFE Universitas Gadjah Mada, 10(1), 81-89.

Radianto, E. (2000). Pendekatan kointegrasi dan ECM terhadap faktor-faktor yang mempengaruhi investasi swasta di Indonesia. Jurnal Ekonomi dan Bisnis (E \& B), $3(1), 1-12$.

Sadeghi, S., Samimi, A. J., \& Sadeghi, S. (2011). Tourism and economic growth in developing cuntries: P-VAR approach. Middle-East Journal of Scientific Research, 10(1), 28-32.

Sadiku, M., Selimi, N., \& Sadiku, L. (2017). The impact of tourism on economic growth in the Western Balkan countries: An empirical analysis. International Journal of Business and Economic Sciences Applied Research, 10(2), 19-25. https://doi.org/10.25103/ijbesar.102.02

Sequeira, T. N., \& Nunes, P. M. (2008). Does tourism influence economic growth? A dynamic panel data approach. Applied Economics, 40(18), 2431-2441. https://doi.org/10.1080/00036840600949520

Solow, R. M. (1956). A contribution to the theory of economic growth. Quarterly Journal of Economics, 7 $(1), 65-94$

Susanti, S. (2013). Pengaruh produk domestik regional bruto, pengangguran dan indeks pembangunan manusia terhadap kemiskinan di Jawa Barat dengan menggunakan analisis data panel. Jurnal Matematika Integratif, 9(1), 1-18. https://doi.org/10.24198/jmi.v9. n1.9374.1-18

Susilawati, M., Jacob, Ch. A., \& Sumarjaya, I.W. (2014). Analisis model regresi data panel tidak lengkap komponen galat dua arah dengan penduga Feasible Generalized Least Square (FGLS). Jurnal Matematika, $4(1), 22-38$

[WTTC] World Travel and Tourism Council. (2019). World travel and tourism economic impact 2019 - March 2019. All rights reseved. Licensed under the Attribution, NonCommercial 4.0 International Creative Commons Licence. http://www.wttc.org.

Yuliana, L., \& Sitorus, Y. M. (2018). Penerapan regresi data panel pada analisis pengaruh infrastruktur terhadap 
produktifitas ekonomi provinsi-provinsi di luar Pulau Jawa Tahun 20102014. Media Statistika, 11(1), 1-15. https://doi.org/10.14710/medstat.11.1.1-15

Yunitaningtyas, K., Yolanda, A. M., \& Indahwati. (2019). A panel data analysis of tourism and economic development in Southeast Asian Countries. IOP Conf. Series: Journal of Physics: Conference Series, 1265: 012028. https://doi.org/10.1088/1742-6596/1265/1/012028
Zeren, K. S. (2018). Determination of number of arriving tourists and night spent in accommodation relations with economic growth: The case of Turkey. Prizren Social Science Journal, 2(2), 210-224.

Zhang, W. B. (2015). Tourism, trade, externalities, and public goodss in a three-sector growth model. Journal of Economics, 6(1), 1-19. 